\title{
Fabrication of carbon coated gadolinia particles for dual-mode magnetic resonance and fluorescence imaging
}

\author{
Timur Sh. ATABAEV ${ }^{a,{ }^{*}}$, Jong Ho LEE ${ }^{b}$, Dong-Wook HAN ${ }^{b}$, Hyung-Kook KIM ${ }^{a,{ }^{*}}$, \\ Yoon-Hwae HWANG ${ }^{a, *}$ \\ ${ }^{a}$ Department of Nanomaterials Engineering, Pusan National University, Miryang 627-706, Republic of Korea \\ ${ }^{b}$ Department of Cogno-Mechatronics Engineering, Pusan National University, Busan 609-735, Republic of Korea
}

Received: October 16, 2014; Revised: January 08, 2015; Accepted: January 12, 2015

(C) The Author(s) 2015. This article is published with open access at Springerlink.com

\begin{abstract}
In the present study, we report a fabrication of dual-mode carbon coated gadolinia $\mathrm{C} @ \mathrm{Gd}_{2} \mathrm{O}_{3}$ particles by a facile hydrothermal synthesis method without using any organic solvents. The prepared $\mathrm{C} @ \mathrm{Gd}_{2} \mathrm{O}_{3}$ particles have a core-shell structure and a narrow size distribution in the range of $261 \pm 27 \mathrm{~nm}$. The fluorescent properties of the prepared C@ $\mathrm{Gd}_{2} \mathrm{O}_{3}$ particles were accessed by a room-temperature photoluminescence study, while the longitudinal relaxivity $\left(r_{1}\right)$ was examined by using a clinical 1.5 T MRI scanner. A murine fibroblast L-929 cell line was used to examine the cytotoxicity and capability of the prepared $\mathrm{C} @ \mathrm{Gd}_{2} \mathrm{O}_{3}$ particles for the fluorescent labeling. The obtained results show that the prepared $\mathrm{C} @ \mathrm{Gd}_{2} \mathrm{O}_{3}$ particles could be used as a dual-mode contrast agent for magnetic resonance and fluorescence imaging.
\end{abstract}

Keywords: carbon; core-shell structure; gadolinia particles; fluorescence; magnetic resonance imaging (MRI) contrast agent

\section{Introduction}

During the last decade, various functional nanoparticles (NPs) with interesting magnetic, optical, and chemical properties have been extensively applied to biomedical areas including imaging, diagnosis, and therapy [1-5]. Among them, "positive" contrast agents (CAs) are widely used to improve the contrast between tissues using $T_{1}$-weighted magnetic resonance imaging (MRI). The higher density of magnetic ions is the main advantage of using paramagnetic gadolinium oxide NPs as a "positive" CA [6]. The resulting gadolinia

* Corresponding authors.

E-mail: T. S. Atabaev, atabaev@snu.ac.kr; H. K. Kim, hkkim@pusan.ac.kr; Y. H. Hwang, yhwang@pusan.ac.kr
NPs covered with biocompatible polyethylene glycol (PEG) have been used in cell labeling studies [6,7]. In particular, thin PEG layer on the surface of $\mathrm{Gd}_{2} \mathrm{O}_{3}$ enhances the steric repulsion between NPs, and prevents protein adhesion that leads no NPs aggregation [8]. However, leaching of free $\mathrm{Gd}^{3+}$ metal ions from these NPs could cause high toxicity towards natural organs and tissues. Therefore, design of new CAs for biomedical application requires a controlled synthesis, with a suitable surface modification in order for them to remain nontoxic and biocompatible. Furthermore, the aqueous dispersion of these CAs should be stable in aqueous media and buffer solutions.

From other point of view, a combination of paramagnetic and fluorescent properties of different materials into a single system might greatly enhance 
their application areas [9]. For example, these bimodal nanostructures can provide an all-in-one diagnostic and therapeutic tool, which can be utilized to treat and visualize diseases simultaneously. Thus, the development of a simple and reliable fabrication method for the synthesis of multifunctional structures with controlled morphologies is still a challenge. In addition, considering that a large dose of $\mathrm{CA}$ is required in a daily imaging process, large-scale process to construct multifunctional CA is still highly needed.

Herein, we design and construct multifunctional carbon coated $\mathrm{Gd}_{2} \mathrm{O}_{3}$ particles. The morphological and structural properties of the synthesized particles were examined using transmission electron microscopy (TEM) and X-ray diffraction (XRD), respectively. As the main focus of this study, the fluorescent and paramagnetic properties of the prepared CA were studied using a photoluminescence machine and a clinical 1.5 T MRI scanner, respectively. From the view of material synthesis, not only the large-scale synthesis but also the surface modification was easily achieved. We believe that a unique particle system composed of $\mathrm{Gd}_{2} \mathrm{O}_{3}$ core and coated with thin carbon layer would have great potential in both bio- and nanoscience.

\section{Experimental}

\section{1 Sample preparation}

Analytical grade $\mathrm{Gd}_{2} \mathrm{O}_{3} \quad(99.9 \%), \mathrm{HNO}_{3} \quad(70 \%)$, dextrose $(\geqslant 99.5 \%)$, and urea $(99.0 \%-100.5 \%)$ were purchased from Sigma-Aldrich and used as received. Spherical $\mathrm{Gd}_{2} \mathrm{O}_{3}$ NPs were fabricated according to the reported protocols $[7,10]$. First, a sealed beaker with a freshly prepared aqueous solution of gadolinium nitrate $\left(0.001 \mathrm{~mol}\right.$ in $40 \mathrm{~mL}$ of $\left.\mathrm{H}_{2} \mathrm{O}\right)$ was placed into an electrical furnace and heated to $90{ }^{\circ} \mathrm{C}$ for $1.5 \mathrm{~h}$. The dried precipitates were then calcined in air at $800{ }^{\circ} \mathrm{C}$ for $1 \mathrm{~h}$ to produce the gadolinia particles. Second, a sealed beaker containing the dispersed $\mathrm{Gd}_{2} \mathrm{O}_{3}$ particles ( $3 \mathrm{mg}$ ) and an aqueous solution of dextrose (4 $\mathrm{g}$ in $40 \mathrm{~mL}$ of $\mathrm{H}_{2} \mathrm{O}$ ) was heated to $180{ }^{\circ} \mathrm{C}$ for $8 \mathrm{~h}$. The suspension was then cooled to room temperature, followed by dialysis in deionized ultrapure water for $24 \mathrm{~h}$, to eliminate the free $\mathrm{Gd}^{3+}$ ions and excess of dextrose. The carbon coated $\mathrm{Gd}_{2} \mathrm{O}_{3}$ particles were isolated by centrifugation and dried at $60{ }^{\circ} \mathrm{C}$ for 1 day.

\section{2 Characterization}

The structure of the prepared powders was examined by XRD (Bruker D8 Discover) using $\mathrm{Cu} \mathrm{K} \alpha$ radiation $(\lambda=0.15405 \mathrm{~nm})$ at a $2 \theta$ scan range of $20^{\circ}-60^{\circ}$. The morphology of the samples was characterized by transmission electron microscopy (TEM; Hitachi H-7600). UV-visible (UV-Vis) absorption spectra were analyzed using a UV-Vis spectrophotometer (Evolution 220). Photoluminescence (PL) measurements were performed using a Hitachi F-7000 spectrophotometer equipped with a $150 \mathrm{~W}$ xenon lamp as the excitation source. Dynamic light scattering (DLS) size measurements were performed using the Malvern Zetasizer Nano ZS machine. The $T_{1}$-weighted images were obtained using a $1.5 \mathrm{~T}$ MRI scanner (General Electric, Signa, HDx1.5T, USA) using the $T_{1}$-weighted spin-echo method (TR/TE $=500 \mathrm{~ms} / 15 \mathrm{~ms}$, field of view $(F O V)=180 \mathrm{~mm} \times 180 \mathrm{~mm}$, slice thickness $=2 \mathrm{~mm}, \quad$ matrix $=256 \times 204$, number of excitations $(\mathrm{NEX})=2)$. All measurements were performed at a room temperature of $22 \pm 1{ }^{\circ} \mathrm{C}$.

\section{3 Cell culture and cytotoxicity assay}

A murine fibroblast cell line (L-929 cells from subcutaneous connective tissue) was obtained from the American Type Culture Collection (ATCC CCL-1 ${ }^{\mathrm{TM}}$, Rockville, MD). The cells were routinely maintained in Dulbecco's modified Eagle's medium (Sigma-Aldrich), supplemented with $10 \%$ fetal bovine serum (Sigma-Aldrich) and 1\% antibiotic antimycotic solution (including 10000 units penicillin, $10 \mathrm{mg}$ streptomycin, and $25 \mathrm{mg}$ amphotericin $\mathrm{B}$ per $\mathrm{mL}$, Sigma-Aldrich) at $37{ }^{\circ} \mathrm{C}$ in $95 \%$ humidity and $5 \% \mathrm{CO}_{2}$. The number of viable cells was indirectly quantified using highly water-soluble tetrazolium salt (WST-8, 2-(2-methoxy-4-nitrophenyl)-3-(4-nitrophenyl)-5-(2, 4 -disulfophenyl)- $2 H$-tetrazolium, monosodium salt) (Dojindo Lab., Kumamoto, Japan), reduced to a water-soluble formazan dye by mitochondrial dehydrogenases. The cell viability was found to be directly proportional to the metabolic reaction products obtained in WST-8. Briefly, the WST- 8 assay was conducted as follows. L-929 cells were treated with increasing concentrations (0-500 ppm) of $\mathrm{C} @ \mathrm{Gd}_{2} \mathrm{O}_{3}$ composite particles and then incubated with WST- 8 for the last $4 \mathrm{~h}$ of the culture periods $(24 \mathrm{~h})$ at $37{ }^{\circ} \mathrm{C}$ in the dark. Parallel sets of wells containing freshly cultured nontreated cells were regarded as negative controls. 
The absorbance was determined to be $450 \mathrm{~nm}$ using an ELISA reader (SpectraMax ${ }^{\circledR}$ 340, Molecular Device Co., Sunnyvale, CA). The relative cell viability was determined as the percentage ratio of the optical densities in the medium (containing the composite particles at each concentration) to that of the fresh control medium.

\section{4 Fluorescence microscopy}

To examine the cellular uptake and distribution of $\mathrm{C} @ \mathrm{Gd}_{2} \mathrm{O}_{3}$ composite particles within the L-929 cells and subsequent cell imaging, the cells were treated with $20 \mathrm{ppm}$ of composite particles for $24 \mathrm{~h}$. After treatment, the cells were fixed with $3.5 \%$ paraformaldehyde (Sigma-Aldrich) in $0.1 \mathrm{M}$ phosphate buffer $(\mathrm{pH}=7)$ for $10 \mathrm{~min}$ at room temperature and immediately observed under a fluorescence microscope (IX81-F72, Olympus Optical, Osaka, Japan).

\section{Results and discussion}

In a typical fabrication procedure, the spherical $\mathrm{Gd}_{2} \mathrm{O}_{3}$ spheres with an average diameter of $243 \pm 38 \mathrm{~nm}$ (Fig. 1(a)) are used as the template cores. A facile hydrothermal method is used to form a thin carbon layer on the surface of $\mathrm{Gd}_{2} \mathrm{O}_{3}$ spheres as shown in Fig. 1(b). The core-shell structure can be clearly observed due to the different electron penetrability of the cores and shells. The cores are black spheres, whereas the shells have a light grey color with a mean thickness of $\sim 17 \mathrm{~nm}$. The average diameters of the samples, as measured by DLS (Fig. 2) before and after carbon coating, are in accordance with the estimated sizes from TEM analysis. These colloidal suspensions are stable for 2-3 days. However, when the mixtures are shaken or ultrasonicated for several seconds, a homogeneous suspension was formed again.

Figure 3 displays the typical XRD patterns of the $\mathrm{Gd}_{2} \mathrm{O}_{3}$ and $\mathrm{C} @ \mathrm{Gd}_{2} \mathrm{O}_{3}$ spheres. All XRD peaks can be assigned easily to the standard cubic $\mathrm{Gd}_{2} \mathrm{O}_{3}$ structure (JCPDS No. 88-2165), which belongs to the Ia3 (206) space group with a lattice constant $a=1.079 \mathrm{~nm}$ $[11,12]$. No additional peaks are observed indicating the formation of a pure cubic $\mathrm{Gd}_{2} \mathrm{O}_{3}$ cubic phase. However, a broad diffraction peak for amorphous carbon is also observed in the case of $\mathrm{C} @ \mathrm{Gd}_{2} \mathrm{O}_{3}$ spheres.

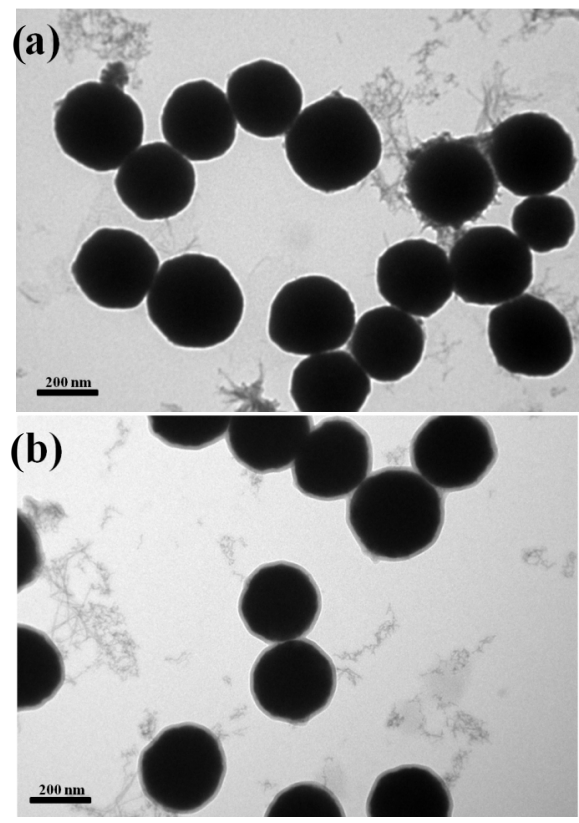

Fig. 1 TEM images of (a) bare $\mathrm{Gd}_{2} \mathrm{O}_{3}$ spheres and (b) carbon coated $\mathrm{Gd}_{2} \mathrm{O}_{3}$ spheres.

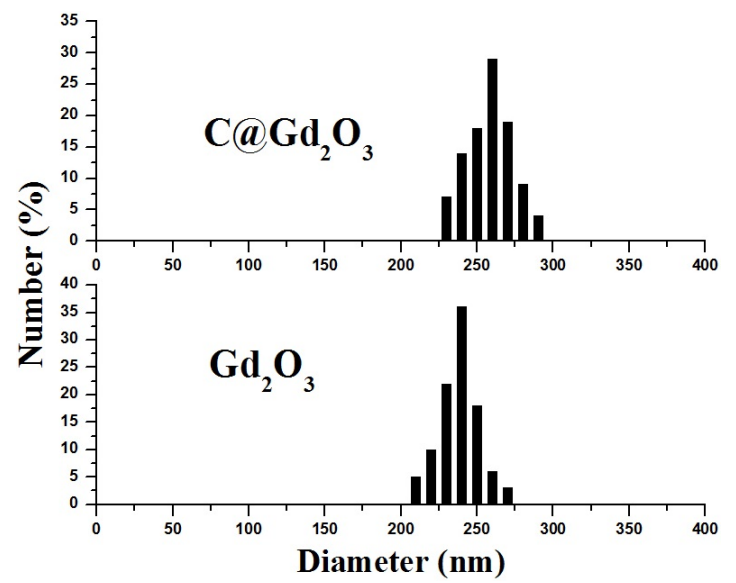

Fig. 2 DLS measurements of the $\mathrm{Gd}_{2} \mathrm{O}_{3}$ and $\mathrm{C} @ \mathrm{Gd}_{2} \mathrm{O}_{3}$ spheres.

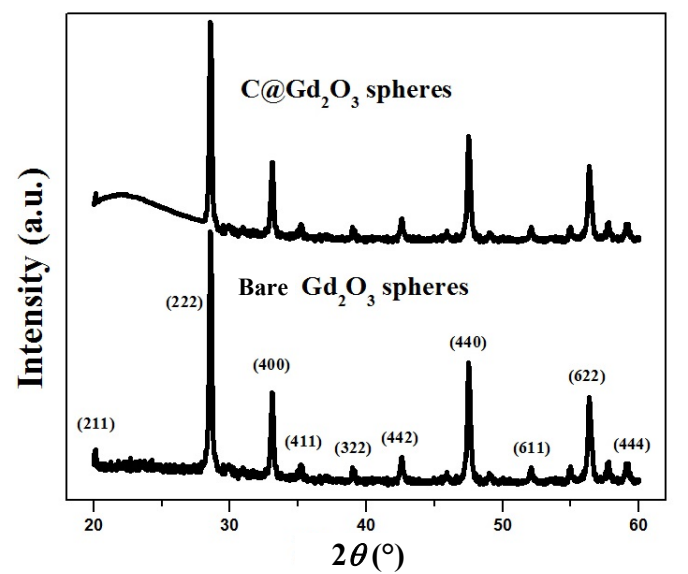

Fig. 3 XRD patterns of bare $\mathrm{Gd}_{2} \mathrm{O}_{3}$ and carbon coated $\mathrm{Gd}_{2} \mathrm{O}_{3}$ spheres. 
Figure 4 shows the UV-Vis absorbance of the $\mathrm{Gd}_{2} \mathrm{O}_{3}$ spheres before and after carbon coating. A red shift in absorption peak is observed after carbon coating on the surface of $\mathrm{Gd}_{2} \mathrm{O}_{3}$ spheres. The absorption of bare $\mathrm{Gd}_{2} \mathrm{O}_{3}$ spheres starts at wavelengths of about $170 \mathrm{~nm}$, shorter than the absorption of $\mathrm{C} @ \mathrm{Gd}_{2} \mathrm{O}_{3}$ spheres. Resulting $\mathrm{C} @ \mathrm{Gd}_{2} \mathrm{O}_{3}$ spheres possess good optical properties (Fig. 4, inset) with a clearly resolved excitation peak (black line, $\lambda_{\max }=362$ $\mathrm{nm}$ ) and an emission peak (red line, $\lambda_{\max }=451 \mathrm{~nm}$ ), which produce bright blue fluorescence. Furthermore, the excitation spectra of $\mathrm{C} @ \mathrm{Gd}_{2} \mathrm{O}_{3}$ spheres are well consistent with the measured UV-Vis absorption spectra. Thus, one can conclude that the surface of the $\mathrm{Gd}_{2} \mathrm{O}_{3}$ spheres is covered with a thin carbon layer.

To evaluate the cytotoxicity of the prepared samples, L-929 cells were treated with various concentrations of particles for $24 \mathrm{~h}$ using a WST- 8 assay. Figure 5

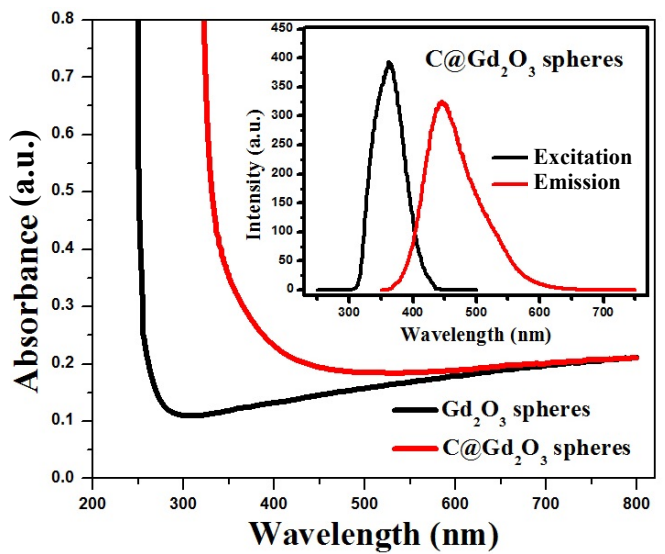

Fig. 4 UV-Vis absorption spectra of the $\mathrm{Gd}_{2} \mathrm{O}_{3}$ and $\mathrm{C} @ \mathrm{Gd}_{2} \mathrm{O}_{3}$ spheres. Inset shows the PL excitation and emission spectra of $\mathrm{C} @ \mathrm{Gd}_{2} \mathrm{O}_{3}$ spheres.

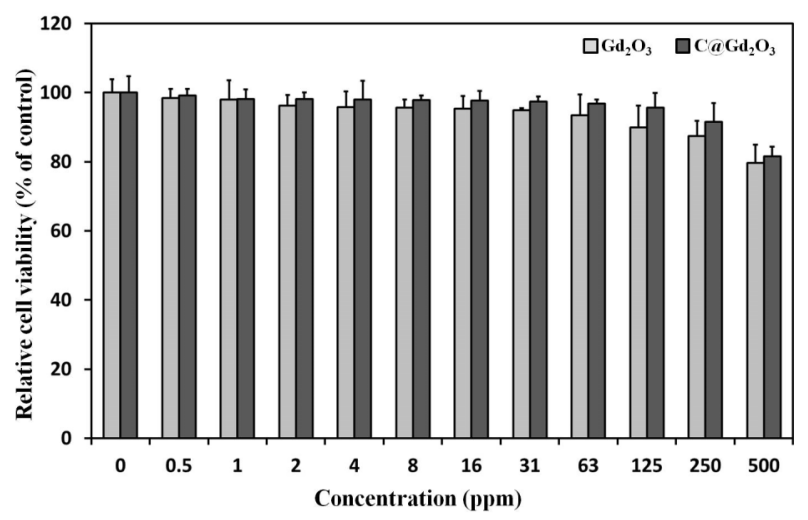

Fig. 5 Dose-dependent responses of L-929 cells to $\mathrm{Gd}_{2} \mathrm{O}_{3}$ and $\mathrm{C} @ \mathrm{Gd}_{2} \mathrm{O}_{3}$ particles. Relative cell viability of L-929 cells exposed for $24 \mathrm{~h}$ to increasing concentrations $(0-500 \mathrm{ppm})$ of samples was evaluated using the WST- 8 assay. shows that the L-929 cells exposed to increasing concentrations $(0-500 \mathrm{ppm})$ of particles for $24 \mathrm{~h}$ show a noticeable dose-dependent decrease in their relative cell viability. The bare $\mathrm{Gd}_{2} \mathrm{O}_{3}$ spheres begin to induce a slight decrease in cell viability from $\sim 10 \mathrm{ppm}$. On the contrary, the $\mathrm{C} @ \mathrm{Gd}_{2} \mathrm{O}_{3}$ particles with a carbon coating result in no significant decrease in cell viability at relatively higher concentrations $\sim 30 \mathrm{ppm}$. These results show that the satisfactory biocompatibility of the $\mathrm{C} @ \mathrm{Gd}_{2} \mathrm{O}_{3}$ particles is at dosages lower than $\sim 30 \mathrm{ppm}$.

To demonstrate the cell imaging potentials of the $\mathrm{C} @ \mathrm{Gd}_{2} \mathrm{O}_{3}$ spheres, the cultured monolayer of L-929 cells was incubated for $24 \mathrm{~h}$ with a particle suspension at a concentration of $20 \mathrm{ppm}$. Figure 6(a) shows that the L-929 cells grow with normal fibroblast-like morphologies after co-labeling with the $\mathrm{C} @ \mathrm{Gd}_{2} \mathrm{O}_{3}$ particles. The obvious blue fluorescence from the C@ $\mathrm{Gd}_{2} \mathrm{O}_{3}$ particles (Fig. 6(b)) is clearly observed, indicating that the $\mathrm{C} @ \mathrm{Gd}_{2} \mathrm{O}_{3}$ particles could make cell imaging possible through the uniform distribution within the cells.

A $1.5 \mathrm{~T}$ clinical MRI scanner was further utilized to demonstrate the potential of the $\mathrm{C} @ \mathrm{Gd}_{2} \mathrm{O}_{3}$ particles for $T_{1}$-weighted MR imaging. Figure 7 shows that the $T_{1}$-relaxation time of the water protons is strongly

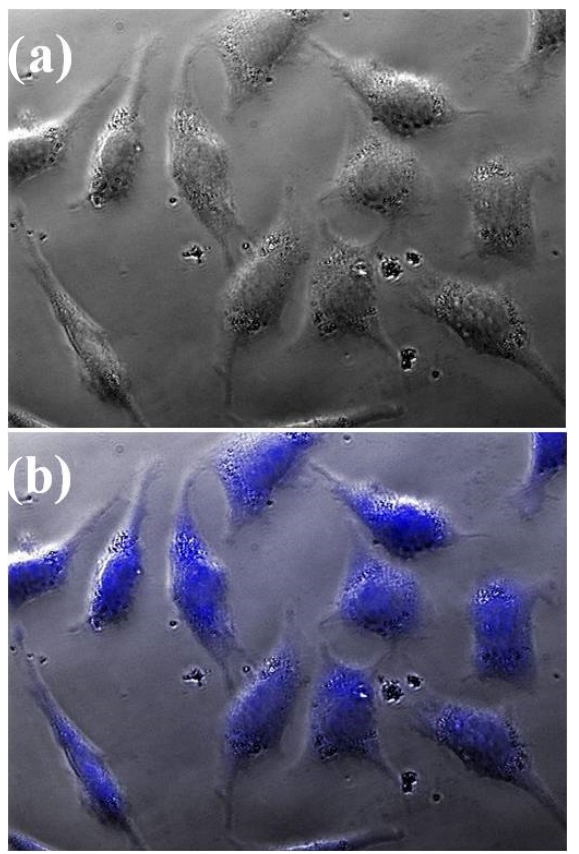

Fig. 6 Fluorescence micrographs $(400 \times)$ of L-929 cells treated with $20 \mathrm{ppm}$ of $\mathrm{C} @ \mathrm{Gd}_{2} \mathrm{O}_{3}$ particles for $24 \mathrm{~h}$. (a) Phase contrast image of the L-929 cells labeled with C@ $\mathrm{Gd}_{2} \mathrm{O}_{3}$ particles; (b) fluorescence image of the L-929 cells labeled with $\mathrm{C} @ \mathrm{Gd}_{2} \mathrm{O}_{3}$ particles. 


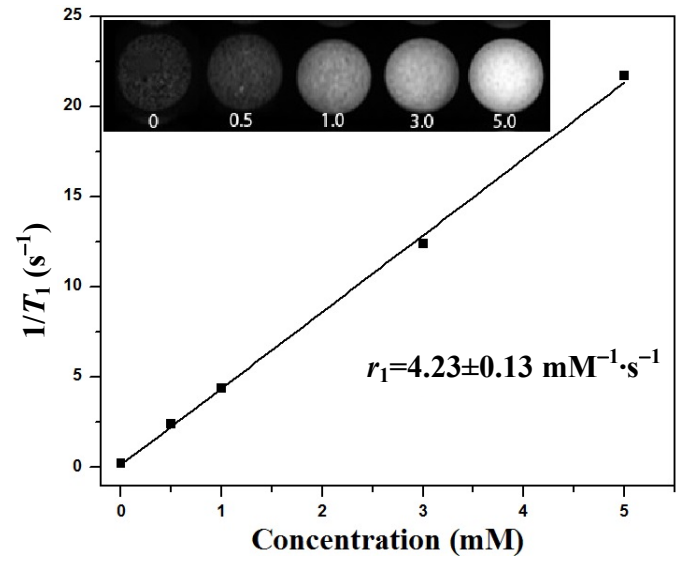

Fig. 7 MRI relaxation rate $\left(1 / T_{1}\right)$ of $\mathrm{C} @ \mathrm{Gd}_{2} \mathrm{O}_{3}$ particles. Inset shows the $T_{1}$-weighted spin-echo MR image of various concentrations of $\mathrm{C} @ \mathrm{Gd}_{2} \mathrm{O}_{3}$ particles in water.

shortened and $T_{1}$-weighted images become brighter as the concentration of the $\mathrm{C} @ \mathrm{Gd}_{2} \mathrm{O}_{3}$ spheres increases. The slope of linear fitting of $1 / T_{1}$ vs. C@ $\mathrm{Gd}_{2} \mathrm{O}_{3}$ concentration yields a longitudinal relaxivity $\left(r_{1}\right)$ value of $4.23 \pm 0.13 \mathrm{mM}^{-1} \cdot \mathrm{s}^{-1}$, which is comparable to commercial Gd chelates (e.g., Gd-DTPA, Gd-DOTA; 4-5 $\mathrm{mM}^{-1} \cdot \mathrm{s}^{-1}$ ) [6]. However, PL results show that the $\mathrm{C} @ \mathrm{Gd}_{2} \mathrm{O}_{3}$ spheres can be also utilized as an effective dual-mode contrast agent for MRI and optical imaging. In addition, the thin carbon coating on the surface of $\mathrm{Gd}_{2} \mathrm{O}_{3}$ spheres can protect tissues from leaching of free toxic $\mathrm{Gd}^{3+}$ metal ions.

\section{Conclusions}

In summary, hydrothermal method was used to produce carbon coated $\mathrm{Gd}_{2} \mathrm{O}_{3}$ particles. The morphology, structural, and optical properties of the synthesized samples were investigated by TEM, XRD, UV-Vis, and PL spectroscopy. MRI relaxivity studies of the $\mathrm{C} @ \mathrm{Gd}_{2} \mathrm{O}_{3}$ particles showed high longitudinal relaxivity $\left(r_{1}=4.23 \pm 0.13 \mathrm{mM}^{-1} \cdot \mathrm{s}^{-1}\right)$ of water protons, suggesting that $\mathrm{C} @ \mathrm{Gd}_{2} \mathrm{O}_{3}$ particles can be used as an efficient $T_{1}$ "positive" contrast agent. The thin carbon layer coated on the surface of $\mathrm{Gd}_{2} \mathrm{O}_{3}$ particles produced bright blue fluorescence, suggesting that the prepared $\mathrm{C} @ \mathrm{Gd}_{2} \mathrm{O}_{3}$ particles could serve as a bimodal agent for MRI and optical imaging.

\section{Acknowledgements}

This study was financially supported by the 2014
Post-Doc, Development Program of Pusan National University. This work was also supported by the National Research Foundation of Korea (NRF) grant funded by the Korea government (MSIP) (No. 2014R1A2A1A11051146).

Open Access: This article is distributed under the terms of the Creative Commons Attribution License which permits any use, distribution, and reproduction in any medium, provided the original author(s) and the source are credited.

\section{References}

[1] Kim T, Hyeon T. Applications of inorganic nanoparticles as therapeutic agents. Nanotechnology 2014, 25: 012001.

[2] Atabaev TS, Urmanova G, Hong NH. Highly mesoporous silica nanoparticles for potential drug delivery applications. Nano Life 2014, 4: 1441003.

[3] Sun L-D, Wang Y-F, Yan C-H. Paradigms and challenges for bioapplication of rare earth upconversion luminescent nanoparticles: Small size and tunable emission/excitation spectra. Acc Chem Res 2014, 47: 1001-1009.

[4] Atabaev TS, Lee JH, Lee JJ, et al. Mesoporous silica with fibrous morphology: A multifunctional core-shell platform for biomedical applications. Nanotechnology 2013, 24: 345603.

[5] Gautam A, van Veggel FCJM. Synthesis of nanoparticles, their biocompatibility, and toxicity behavior for biomedical applications. J Mater Chem B 2013, 1: 5186-5200.

[6] Faucher L, Tremblay M, Lagueux J, et al. Rapid synthesis of PEGylated ultrasmall gadolinium oxide nanoparticles for cell labeling and tracking with MRI. ACS Appl Mater Interfaces 2012, 4: 4506-4515.

[7] Atabaev TS, Lee JH, Han D-W, et al. Ultrafine PEG-capped gadolinia nanoparticles: Cytotoxicity and potential biomedical applications for MRI and luminescent imaging. RSC Adv 2014, 4: 34343-34349.

[8] Kingshott P, Thissen H, Griesser HJ. Effects of cloud-point grafting, chain length, and density of PEG layers on competitive adsorption of ocular proteins. Biomaterials 2002, 23: 2043-2056.

[9] Atabaev TS, Kim H-K, Hwang Y-H. Fabrication of bifunctional core-shell $\mathrm{Fe}_{3} \mathrm{O}_{4}$ particles coated with ultrathin phosphor layer. Nanoscale Res Lett 2013, 8: 357.

[10] Ajmal M, Atabaev TS. Facile fabrication and luminescent properties enhancement of bimodal $\mathrm{Y}_{2} \mathrm{O}_{3}: \mathrm{Eu}^{3+}$ particles by simultaneous $\mathrm{Gd}^{3+}$ codoping. Opt Mater 2013, 35: $1288-1292$.

[11] Jia G, You H, Liu K, et al. Highly uniform $\mathrm{Gd}_{2} \mathrm{O}_{3}$ hollow microspheres: Template-directed synthesis and luminescence properties. Langmuir 2010, 26: 5122-5128.

[12] Atabaev TS, Piao Z, Hwang Y-H, et al. Bifunctional $\mathrm{Gd}_{2} \mathrm{O}_{3}: \mathrm{Er}^{3+}$ particles with enhanced visible upconversion luminescence. J Alloys Compd 2013, 572: 113-117. 